\title{
THE OCCURRENCE OF Fusarium poae (Peck) Wollenw. ON OAT (Avena sativa L.) PANICLES AND ITS HARMFULNESS
}

\author{
${ }^{1}$ Irena Kiecana, ${ }^{1}$ Małgorzata Cegiełko, ${ }^{1}$ Elżbieta Mielniczuk, ${ }^{2}$ Juliusz Perkowski \\ ${ }^{1}$ Department of Phytopathology and Mycology, University of Life Sciences in Lublin, \\ ul. Leszczyńskiego 7, 20-069 Lublin, Poland \\ ${ }^{2}$ Department of Chemistry, University of Life Sciences in Poznań \\ e-mail: irena.kiecana@up.lublin.pl
}

Received: 10.05.2012

\section{Abstract}

Field observations of oat panicles carried out in the fields of Danko Plant Breeding Company in the period 2006-2007 and in the fields of Strzelce Plant Breeding Company in 2008 showed the occurrence of panicles with Fusarium head blight symptoms in each growing season. In 2006 the percentage of such panicles ranged from 0.25 to $1.5 \%$, in 2007 from 2.0 to $9.0 \%$, whereas in 2008 from 0.5 to $8.0 \%$. The species Fusarium poae was the main causal agent of Fusarium head blight. A study on inoculation of panicles of 12 genotypes of oats with Fusarium poae strain no. 35, which was conducted in 2008 in experimental fields near the city of Zamość, determined the number of kernels per panicle, grain yield from 40 panicles $(4 \times 10$ panicles), and 1000-kernels weight (TKW) after the harvest of the crop at full grain maturity. Compared to the control, the lowest reduction in the number of kernels per panicle was found in the case of the cultivar 'Krezus' (88.69\% of the control), while the highest one in 'Szakal' (22.46\% of the control). As a result of inoculation of panicles with $F$. poae, the breeding line STH 8107 was characterized by the lowest decrease in kernels yield (69.76\% of the control), whereas the highest decrease was found in the breeding line CHD $1430 / 02$ (14.26\% of the control). Compared to the control, the lowest reduction in TKW was observed in the breeding line STH 8107 (96.46\% of the control), whereas the highest one in the breeding line CHD 1430/02 (45.06\% of the control). The presence of secondary metabolites of $F$. poae and group A trichothecene compounds: HT-2 toxins (from 0 to $0.013 \mathrm{mg} \times \mathrm{kg}^{-1}$ ), diacetoxyscirpenol (DAS) (from 0 to $0.002 \mathrm{mg} \times \mathrm{kg}^{-1}$ ), T-2 tetraol (from 0.001 to $0.014 \mathrm{mg} \mathrm{x} \mathrm{g}^{-1}$ ), and scirpentriol (from 0.008 to $0.074 \mathrm{mg}$ $\left.\times \mathrm{kg}^{-1}\right)$, was found in infected oat kernels. Group B trichothecenes: nivalenol (from 0 to $0.157 \mathrm{mg} \times \mathrm{g}^{-1}$ ), deoxynivalenol (DON) (from 0 to $0.127 \mathrm{mg} \times \mathrm{kg}^{-1}$ ) as well as its acetylated derivatives: 3-AcDON (from 0 to $0.059 \mathrm{mg} \times \mathrm{kg}^{-1}$ ) and 15-Ac DON (from 0 to $\left.0.288 \mathrm{mg} \times \mathrm{kg}^{-1}\right)$, were also present in oat kernels obtained from panicles artificially infected with Fusarium poae.

Key words: oats, genotypes, Fusarium poae, Fusarium head blight, trichothecene compounds

\section{INTRODUCTION}

The first reports on the occurrence of Fusarium head blight in oats come from the 1920's and they relate to crops in the state of Indiana in the United States of America, but the authors did not mention the species responsible for this disease (M a in s et al. 1929, according to Parry et al. 1995). At the beginning of the 20th century, Fusarium graminearum Schwabe was considered to be the main cause of Fusarium head blight in oats in Wales (M o or e, 1929, according to Parry et al. 1995). Fusarium poae (Peck) Wollenw. proved to be the main cause of this disease in oats grown in the state of Manitoba (Canada) in the years 1993 and 1994, whereas in 2002 and 2003 it ranked second, after $F$. graminearum, as the casual agent of Fusarium head blight in oats grown in this region (T e k a u z et al. 2004; D e s j a r d i n s, 2006). In Denmark in the period 2003-2007, Fusarium poae belonged to the species that were dominant in causing Fusarium head blight in oats, alongside with $F$. langsethiae sp. nov. Torp and Nirenberg as well as $F$. avenaceum (Fr.) Sacc. (N i e l s e n et al. 2010).

Under the conditions of south-eastern Poland, $F$. poae ranked second in importance, after Fusarium avenaceum, in causing Fusarium head blight in oats grown in this region in the period 1996-1998 (M i e l$\mathrm{niczuk}, 2001$ ), while in 2000 it proved to be the dominant fungus among Fusarium species in infected panicles (K i e c a n a et al. 2005).

Grain (Mielniczuk et al. 2010) and post-harvest residues ( Mc Mulle $\mathrm{n}$ and Stack, 1983) are the primary source of inoculum of fungi causing Fusarium head blight in cereals. Weeds can be an important source of inoculum of Fusarium spp. (F a r r et al. 1989, according to $S \mathrm{~h}$ a n e r, 2003). 
In oat grain infected by Fusarium poae, the occurrence of the following trichothecene compounds has been found: nivalenol (NIV), deoxynivalenol (DON), diacetoxyscirpenol (DAS), monoacetoxyscirpenol (MAS), scirpentriol (STO), fusarenon-X (FUS-X), T-2 toxins, HT-2 toxins, and neosolaniol (NEO) (L a n g seth et al. 1997; Ki e c an a and Perkow ski, 1998; Ki ec an a et al. 2005; P arikka et al. 2010). Moreover, F. poae can produce metabolites such as: beauvericin, butenolide, culmorin, cyclonerodiol, enniatins, and fusarin $\mathrm{C}$ (F a b e r and A n d e r s, 1986a; Thrane, 1989; 2001; De Nijs et al. 1996; L ogrieco et al. 1998b; 2002a, according to Des j ardins, 2006).

Due to an increase in the percentage of Fusarium poae in the species composition of fungi colonizing cereal grain, a study was undertaken to determine the contribution of $F$. poae to infection of panicles of oats grown in two Polish regions and to assess the harmfulness of the above-mentioned species to some genotypes of this cereal.

\section{MATERIALS AND METHODS}

Field observations of Fusarium head blight in oats Avena sativa L.were carried out in the period 2006-2007. In the years 2006 and 2007, the study was conducted in the fields of Danko Plant Breeding Company (located in Wielkopolska Voivodeship (region)) where the genotypes were grown on podzolic soil, while in 2008 it was carried out in the fields of Strzelce Plant Breeding Company (located in Łódź Voivodeship) with typical brown soil. A list of cultivars and breeding lines is shown in Fig. 1. Each year, the occurrence of Fusarium head blight was studied at full grain maturity (92 in the Zadoks scale according to Tottman, 1987). The study material consisted of 100 successive panicles collected from four places of the field, that is, a total of 400 panicles of each genotype were examined, among which the number of panicles with Fusarium head blight symptoms was determined. 20 panicles from each cultivar and breeding line were sampled for laboratory analysis. In the laboratory, kernels and chaff were separated from the sampled panicles in order to isolate fungi by the method described earlier by $\mathrm{Kiec}$ an a and Mielni c zuk (2010) and using mineral medium (M i e l n i c z u k et al. 2010). 50 kernels and 50 chaff (chaff) from the panicles collected from a single study area were analysed.

Fungi of the genus Fusarium were identified using the keys and monographs referenced in the paper by Kiecana and Mielniczuk (2010).

A strictly controlled experiment with panicle inoculation was conducted in 2008 in experimental fields near the city of Zamość on leached brown soil derived from loess deposits. The study included 12 genotypes of oats (Table 2) and Fusarium poae strain no. 35 , with its pathogenicity proved by the method of Mishra and B ehr (1976). The harmfulness of $F$. poae to panicles of 12 genotypes of oats was determined on the basis of a field experiment with artificial inoculation of panicles with $F$. poae no. 35 during flowering. Infectious material was prepared following Mesterházy (1978), but with a modification since the fungus was cultured on SNA medium based on a decoction of oat leaves ( $\mathrm{K} \mathrm{i} \mathrm{e} \mathrm{c} \mathrm{an} \mathrm{a} \mathrm{et} \mathrm{al.} \mathrm{2002).} \mathrm{The}$ method of inoculation of panicles in field was the same as in the case of barley (K i e c a n a, 1994). The infectious material consisted of a suspension of coinidia of $F$. poae no. 35 with a density of $5 \times 10^{5} \times 1 \mathrm{ml}^{-1}$. Plants whose panicles were inoculated and control plants were grown in $10 \mathrm{~m}^{2}$ plots. There were $1 \mathrm{~m}$ wide buffer strips and $50 \mathrm{~cm}$ wide paths between the plots. Panicles were inoculated at the flowering stage, which was between 27 June and 2 July 2008. 80 panicles of each genotype were inoculated with the infectious fungal material and 20 panicles were considered to be one replication. Inoculation was performed using a garden sprayer and $4 \mathrm{ml}$ of infectious material per 1 panicle. Panicles sprayed only with sterile distilled water were the control. After inoculation, the panicles were covered with plastic bags and in this way the infectious material was protected against air currents and drying for 48 hours.

At full grain maturity (92 in the Zadoks scale according to Tottma n, 1987), inoculated and control panicles were cut off and kernels were separated; subsequently, the number of kernels per panicle was determined in 40 panicles $(4 \times 10$ panicles $)$ as well as kernels yield obtained from them and 1000 kernels weight. The obtained results were statistically analysed using analysis of variance and Tukey's multiple confidence intervals. Tukey's least significant differences were calculated for a significance level of $\leq 0.05$ ( $\dot{\mathrm{Z}} \mathrm{u} \mathrm{k}, 1989$ ).

In the grain samples obtained from panicles artificially infected with $F$. poae, an analysis of the content of Fusarium toxins was performed at the Department of Chemistry of the Poznan University of Life Sciences.

To determine the content of group A and B trichothecenes, the grain samples were extracted with a mixture of acetonitrile/water (82:18, v/v) and subsequently they were purified using columns filled with $5 \mathrm{~cm}^{3}$ of a mixture of activated carbon (Draco G 60, 100 mesh), celite (Celite 545), and neutral aluminium oxide (70-230 mesh), mixed at a weight ratio of 1:1:1.

Group A trichothecenes were analysed as trifluoroacetylated derivatives, while group B trichothecenes as trimethylsilyl derivatives. The analysis was performed in the selected ion monitoring (SIM) mode. For 
group A trichothecenes, these were: STO 456 and 555; T-2 tetraol 455 and 568; T-2 triol 455 and 569; DAS 402 and 374; HT-2 455 and 327; T-2 327 and 401; as well as Mirex 332 and 509. Retention time for these toxins was, respectively: $14.71 ; 15.18 ; 18.23 ; 18.62$; 19.54; 21.56; and 21.32 minutes.

To identify group B trichothecenes, SIM analysis was also performed. These were: for DON ions 103 and 512; 3-AcDON 117 and 482; 15-AcDON 193 and 482; FUS 103 and 570; NIV 191 and 600. Retention time for these toxins was, respectively: $19.53 ; 20.88$; 21.07; 21.01; and 21.25 minutes.

To confirm the presence of the identified toxins in the sample, a full mass range (from 100 to $700 \mathrm{amu}$ ) analysis was performed which produced a mass spectrum that was compared to the reference spectrum obtained in the same way. This spectrum, together with a comparison of retention times of the compound in question with the reference standard, is the basis for the identification of toxins. In addition to the qualitative analysis, the concentrations of the examined toxins were determined by comparing the relative heights of selected ions. The obtained results were processed using Chem Station software and the quantitative content of toxins in the oat samples assayed was determined.

Information on weather patterns in the study area was obtained from the Zamość-based Faculty of Agricultural Sciences of the University of Life Sciences in Lublin.

\section{RESULTS}

The field observations carried out at full grain maturity in the fields of Danko Plant Breeding Company and Strzelce Plant Breeding Company showed that plants with ears exhibiting Fusarium head blight symptoms occurred each year. In 2006 the percentage of panicles with Fusarium head blight symptoms ranged from 0.25 to $1.5 \%$, in 2007 from 2.0 to $9.0 \%$, whereas in 2008 from 0.5 to $8.0 \%$ (Fig. 1). As a result of mycological analysis of kernels and chaff collected from the panicles with Fusarium head blight symptoms, 2383 fungal isolates were isolated (Table 1). Depending on the growing period, colonies of fungi of the genus $\mathrm{Fu}$ sarium isolated from kernels and chaff accounted for, respectively: $24.5 \%$ (2006), $48.7 \%$ (2007), and $26.0 \%$ (2008) of all fungal isolates (Table 1). Fungi of the genus Fusarium were represented by $F$. avenaceum, $F$. crookwellense, $F$. culmorum, $F$. graminearum, $F$. oxysporum, F. poae, and F. sporotrichioides (Table 1; Fig. 2). Isolates of other fungi belonged to the following: Alternaria alternata, Aspergillus flavus, Bipolaris sorokiniana, Botrytis cinerea, Chaetomium globosum, Cladosporium cladosporioides, Drechslera avenae, Epicoccum nigrum, Gilmaniella humicola,
Humicola fuscoatra, Mucor hiemalis, Penicillium nigricans, Penicillium verrucosum var. cyclopium, $\mathrm{Pe}$ riconia macrospinosa, Torula herbarum as well as to non-sporulating forms. Irrespective of the place of cultivation and year, the species $F$. poae commonly infected grain and chaff in question. In the period 20062008 , isolates of this species accounted for $29.7 \%$ to $52.5 \%$ of isolates of all Fusarium spp. in the case of kernels and for $15.0 \%$ to $34.5 \%$ in the case of chaff (Fig. 2).

Inoculation of panicles with $F$. poae strain proved to be effective. The panicles exhibited symptoms of premature whitening of heads. Kernels derived from inoculated panicles were small, light, and soft, while kernels obtained at that time from control panicles were properly developed. Artificial infection of panicles with $F$. poae had a significant effect on reducing the number of kernels per panicle in 10 oat genotypes, compared to the control; 'Chwat' and 'Krezus' were an exception. The lowest reduction in the number of kernels per panicle, compared to the control, was found in the case of 'Krezus' ( $88.69 \%$ of the control), whereas the highest one in 'Szakal' (22.46\% of the control) (Table 2). Significant differences in kernels yield, compared to the control, were observed in all genotypes tested; the breeding line STH 8107, in the case of which kernels yield accounted for $69.76 \%$ of the control, was characterized by the lowest decrease in grain yield as a result of inoculation of panicles with $F$. poae, while the highest decrease was recorded in the breeding line CHD 1430/02 - 14.26\% of the control (Table 2). The statistical analysis of TKW found that artificial inoculation of panicles with $F$. poae resulted in a significant decrease in 1000 kernels weight in 9 oat genotypes. Compared to the control, the lowest reduction in TKW was found in the case of the breeding line STH 8107 (96.46\% of the control) and the highest one in the breeding line CHD 1430/02 (45.06\% of the control) (Table 2).

The analysis of secondary metabolites of $F$. poae showed the presence of group A trichothecene compounds: HT-2 toxins, diacetoxyscirpenol (DAS), $\mathrm{T}-2$ tetraol, and scirpentriol, in infected oat kernels. The content of HT-2 toxin was from $0.01 \mathrm{mg} \times \mathrm{kg}^{-1}$ for the breeding line CHD 1430/02 to $0.013 \mathrm{mg} \times \mathrm{kg}^{-1}$ for ' $\mathrm{Ko}$ neser'. In the case of the breeding line CHD 1375/00, this metabolite was not found to occur. The presence of diacetoxyscirpenol was found in 11 grain samples assayed, except for the cultivar 'Chwat'. The contamination of oat grain with the above-mentioned metabolite was from $0.001 \mathrm{mg} \times \mathrm{kg}^{-1}$ for 'Krezus', 'Szakal', 'Zuch', CHD 1375/00, CHD 1430/02, and STH 8307 to $0.002 \mathrm{mg} \times \mathrm{kg}^{-1}$ in the case of the genotypes 'Haker', 'Koneser', 'Polar', 'Sławko', and STH 8107. The content of T-2 tetraol in the grain samples assayed ranged 
between $0.001 \mathrm{mg} \times \mathrm{kg}^{-1}$ (CHD 1375/00, STH 8107) and $0.014 \mathrm{mg} \times \mathrm{kg}^{-1}$ ('Haker', 'Koneser'). The concentration of scirpentriol in grain of the tested genotypes of oats was from $0.008 \mathrm{mg} \times \mathrm{kg}^{-1}$ (STH 8107) to $0.074 \mathrm{mg}$ $\times \mathrm{kg}^{-1}$ ('Haker') (Table 3).

The presence of group B trichothecenes - nivalenol, deoxynivalenol and its acetylated derivatives (3-Ac DON, 15-Ac DON), was also found in grain derived from panicles artificially infected with Fusarium poae. The presence of deoxynivalenol (DON) was detected in the case of seven oat genotypes at a level from 0.036 ('Zuch') to $0.127 \mathrm{mg} \times \mathrm{kg}^{-1}$ ('Szakal'), while the presence of 15-Ac DON was observed in the case of eight genotypes at a concentration from 0.017 ('Zuch') to 0.288 (STH 8107). 3-Ac DON was found to be present only in 'Szakal' at a level of $0.059 \mathrm{mg} \times \mathrm{kg}^{-1}$. Oat grain contamination with nivalenol was observed in most of the genotypes assayed, except for cv. 'Krezus' and the breeding line STH 8107 . The highest amounts of this compound $\left(0.157 \mathrm{mg} \times \mathrm{kg}^{-1}\right)$ were found in grain of the breeding line CHD 1430/02 (Table 3).

In Zamość, the 2008 growing season was characterized by temperature higher than the long-term mean in April, May, June, July, and August by $+2.2^{\circ} \mathrm{C}$ up to $+3.5^{\circ} \mathrm{C}$. The percent of normal rainfall, as compared to the long-term mean, was higher in April, May, July, and August by $11.3 \%$ up to $91.7 \%$, whereas in June 2008 it was $64.8 \%$ of normal rainfall (Table 4).

Table 1

Fungi isolated from oat kernels and chaff in 2006-2008

\begin{tabular}{|c|c|c|c|c|c|c|c|c|c|c|c|}
\hline \multirow{2}{*}{ No. } & \multirow{2}{*}{ Fungal species } & \multicolumn{3}{|c|}{2006} & \multicolumn{3}{|c|}{2007} & \multicolumn{3}{|c|}{2008} & \multirow{2}{*}{$\begin{array}{c}\text { Total number } \\
\text { of isolates }\end{array}$} \\
\hline & & 1 & 2 & 3 & 1 & 2 & 3 & 1 & 2 & 3 & \\
\hline 1 & Fusarium avenaceum (Fr.) Sacc. & 32 & 20 & 52 & 37 & 19 & 56 & 54 & 40 & 94 & 202 \\
\hline 2 & $\begin{array}{l}\text { Fusarium crookwellense Burgess, } \\
\text { Nelson \& Toussoun }\end{array}$ & - & - & - & 27 & 11 & 38 & - & - & - & 38 \\
\hline 3 & Fusarium culmorum (W. G. Sm.) Sacc. & 14 & 8 & 22 & 108 & 72 & 180 & 12 & 8 & 20 & 222 \\
\hline 4 & Fusarium graminearum Schwabe & - & - & - & 5 & 0 & 5 & - & - & - & 5 \\
\hline 5 & Fusarium oxysporum Schl. & 1 & 2 & 3 & - & - & - & - & - & - & 3 \\
\hline 6 & Fusarium poae (Peck) Wollenw. & 63 & 20 & 83 & 81 & 40 & 121 & 67 & 10 & 77 & 281 \\
\hline 7 & Fusarium sporotrichioides Sherb. & 10 & 8 & 18 & 15 & 11 & 26 & 3 & 9 & 12 & 56 \\
\hline \multirow[t]{2}{*}{8} & Other colonies & 250 & 299 & 549 & 216 & 233 & 449 & 242 & 336 & 578 & 1576 \\
\hline & Total & 370 & 357 & 727 & 489 & 386 & 875 & 378 & 403 & 781 & 2383 \\
\hline
\end{tabular}

1- kernels; 2 - chaff; 3 - kernels + chaff

Table 2

Effect of artificial inoculation of oat panicles with Fusarium poae on the number of kernels per panicle, kernels yield, and 1000 kernels weight

\begin{tabular}{|c|c|c|c|c|c|c|c|c|c|}
\hline \multirow{2}{*}{$\begin{array}{c}\text { Oat } \\
\text { genotypes }\end{array}$} & \multicolumn{2}{|c|}{$\begin{array}{l}\text { Average number of } \\
\text { kernels per panicle }\end{array}$} & \multirow{2}{*}{$\begin{array}{l}\% \text { of the } \\
\text { control }\end{array}$} & \multicolumn{2}{|c|}{$\begin{array}{l}\text { Average grain yield } \\
\text { per } 10 \text { panicles }(\mathrm{g})\end{array}$} & \multirow{2}{*}{$\begin{array}{l}\% \text { of the } \\
\text { control }\end{array}$} & \multicolumn{2}{|c|}{$\begin{array}{l}\text { Average } 1000 \text { grain } \\
\text { weight }(\mathrm{TKW})(\mathrm{g})\end{array}$} & \multirow{2}{*}{$\begin{array}{c}\% \\
\text { of the control }\end{array}$} \\
\hline & F. poae & Control & & F. poae & Control & & F. poae & Control & \\
\hline Chwat & 60.20 & 70.13 & 85.84 & $17.10 *$ & 29.06 & 58.84 & $21.65 *$ & 41.38 & 52.32 \\
\hline Haker & $42.83 *$ & 107.38 & 39.89 & $11.25^{*}$ & 34.89 & 32.24 & $26.08 *$ & 33.27 & 78.39 \\
\hline Koneser & $58.13 *$ & 110.30 & 52.70 & $11.25^{*}$ & 35.90 & 31.34 & 30.21 & 32.21 & 93.79 \\
\hline Krezus & 76.83 & 86.63 & 88.69 & $16.10 *$ & 28.04 & 57.42 & $16.13 *$ & 32.57 & 49.52 \\
\hline Polar & $32.23 *$ & 61.98 & 52.00 & $5.93 *$ & 20.52 & 28.90 & 29.81 & 33.15 & 89.92 \\
\hline Sławko & $74.54 *$ & 90.13 & 82.70 & $20.36 *$ & 32.82 & 62.03 & $27.34 *$ & 36.36 & 75.19 \\
\hline Szakal & $18.65^{*}$ & 83.03 & 22.46 & $5.22 *$ & 28.66 & 18.21 & $28.29 *$ & 34.58 & 81.81 \\
\hline Zuch & $38.00 *$ & 123.55 & 30.76 & $9.20 *$ & 35.91 & 25.62 & $23.59 *$ & 29.06 & 81.18 \\
\hline CHD 1375/00 & $29.05^{*}$ & 87.35 & 33.26 & $6.76^{*}$ & 33.30 & 20.30 & $23.22 *$ & 38.18 & 60.82 \\
\hline CHD 1430/02 & $27.23 *$ & 86.53 & 31.47 & $5.43 *$ & 38.08 & 14.26 & $19.90 *$ & 44.16 & 45.06 \\
\hline STH 8107 & $48.93 *$ & 74.45 & 65.72 & $18.32 *$ & 26.26 & 69.76 & 36.02 & 37.34 & 96.46 \\
\hline STH 8307 & $31.28 *$ & 47.85 & 65.37 & $7.79 *$ & 15.62 & 49.87 & $24.84 *$ & 32.67 & 76.03 \\
\hline
\end{tabular}

* Compared to the control, the means differ significantly at $\mathrm{P} \leq 0.05$. 
Table 3

Content of mycotoxins $\left(\mathrm{mg} \times \mathrm{kg}^{-1}\right)$ in oat grain obtained from panicles artificially inoculated with $F$. poae

\begin{tabular}{lcccccccc}
\hline \multirow{2}{*}{ Oat genotypes } & \multicolumn{4}{c}{ Type B } & \multicolumn{4}{c}{ Type A } \\
\cline { 2 - 9 } Chwat & DON & 3-AcDON & 15 -AcDON & NIV & STO & T-2 Tetraol & DAS & HT-2 \\
\hline Haker & 0.000 & 0.000 & 0.028 & 0.087 & 0.029 & 0.009 & 0.000 & 0.007 \\
Koneser & 0.090 & 0.000 & 0.078 & 0.064 & 0.074 & 0.014 & 0.002 & 0.006 \\
Krezus & 0.000 & 0.000 & 0.127 & 0.111 & 0.042 & 0.014 & 0.002 & 0.013 \\
Polar & 0.070 & 0.000 & 0.277 & 0.000 & 0.034 & 0.005 & 0.001 & 0.004 \\
Sławko & 0.000 & 0.000 & 0.171 & 0.073 & 0.029 & 0.006 & 0.002 & 0.004 \\
Szakal & 0.096 & 0.000 & 0.000 & 0.035 & 0.026 & 0.004 & 0.002 & 0.002 \\
Zuch & 0.127 & 0.059 & 0.000 & 0.035 & 0.034 & 0.007 & 0.001 & 0.008 \\
CHD 1375/00 & 0.036 & 0.000 & 0.017 & 0.050 & 0.019 & 0.003 & 0.001 & 0.002 \\
CHD 1430/02 & 0.000 & 0.000 & 0.000 & 0.019 & 0.010 & 0.001 & 0.001 & 0.000 \\
STH 8107 & 0.068 & 0.000 & 0.058 & 0.157 & 0.052 & 0.005 & 0.001 & 0.001 \\
STH 8307 & 0.000 & 0.000 & 0.288 & 0.000 & 0.008 & 0.001 & 0.002 & 0.002 \\
\hline Mean & 0.067 & 0.000 & 0.000 & 0.019 & 0.013 & 0.003 & 0.001 & 0.002 \\
\hline DON - & 0.0462 & 0.0049 & 0.0870 & 0.0542 & 0.0308 & 0.0060 & 0.0013 & 0.0043 \\
\hline
\end{tabular}

DON - deoxynivalenol, NIV - nivalenol, STO - scirpentriol, DAS - diacetoxyscirpenol

Table 4

Temperature and rainfall in the Zamość area in the 2008 oat growing season

\begin{tabular}{|c|c|c|c|c|}
\hline \multirow{2}{*}{ Month } & \multicolumn{2}{|c|}{ Long-term mean (1951-1975) } & \multirow{2}{*}{$\begin{array}{c}\text { Deviations } \\
\text { in air temperatures }\end{array}$} & \multirow{2}{*}{$\begin{array}{l}\text { Percent of normal } \\
\text { monthly rainfall }\end{array}$} \\
\hline & Air temperature $\left[{ }^{\circ} \mathrm{C}\right]$ & Rainfall [mm] & & \\
\hline April & 7.5 & 37.3 & +3.2 & 191.7 \\
\hline May & 12.5 & 67.2 & +2.5 & 111.3 \\
\hline June & 16.7 & 75.5 & +2.7 & 64.8 \\
\hline July & 18.0 & 82.1 & +2.2 & 169.7 \\
\hline August & 17.1 & 72.4 & +3.5 & 137.7 \\
\hline
\end{tabular}

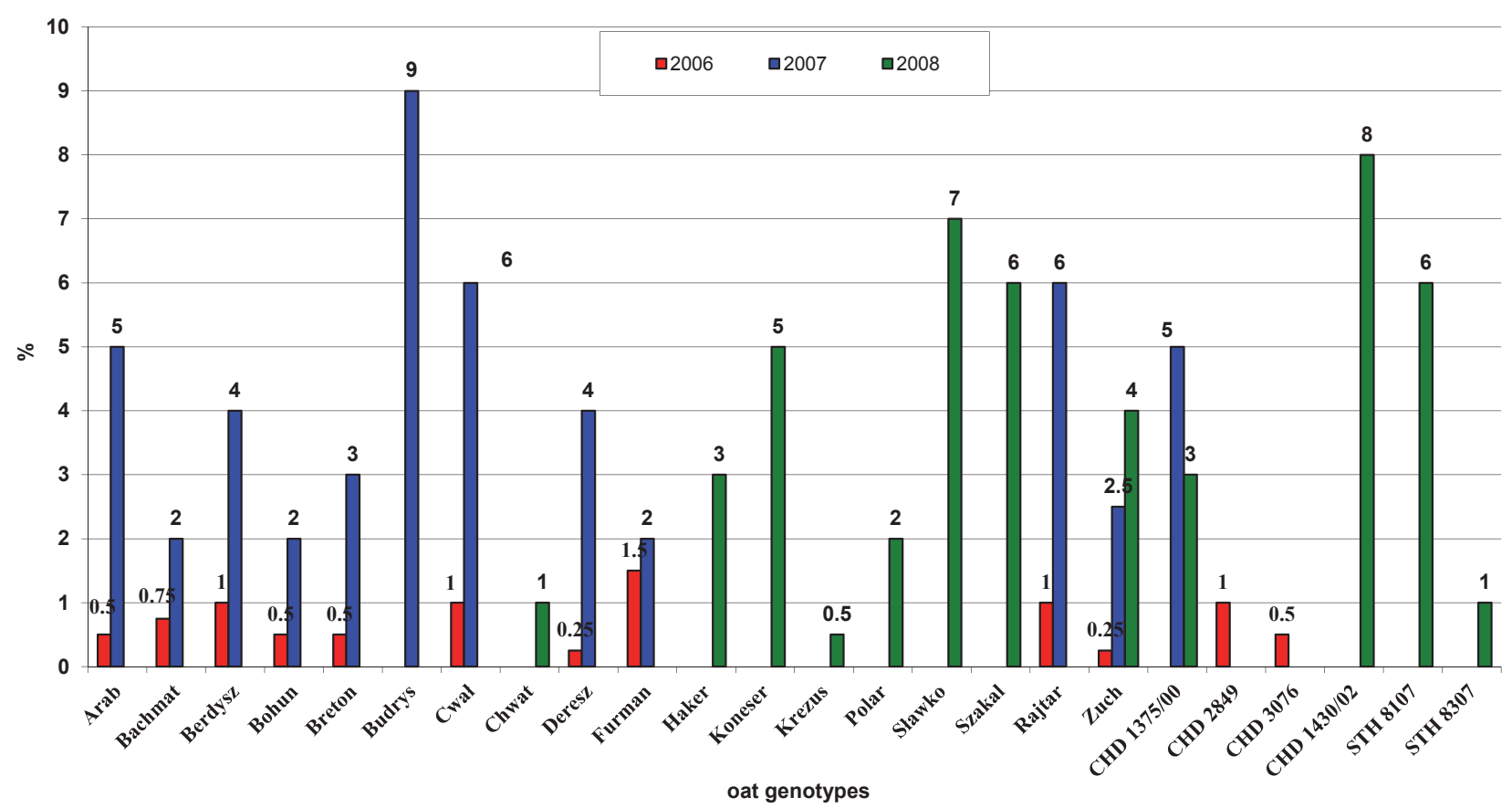

Fig. 1. Percentage of oat panicles with Fusarium head blight symptoms in 2006-2008. 


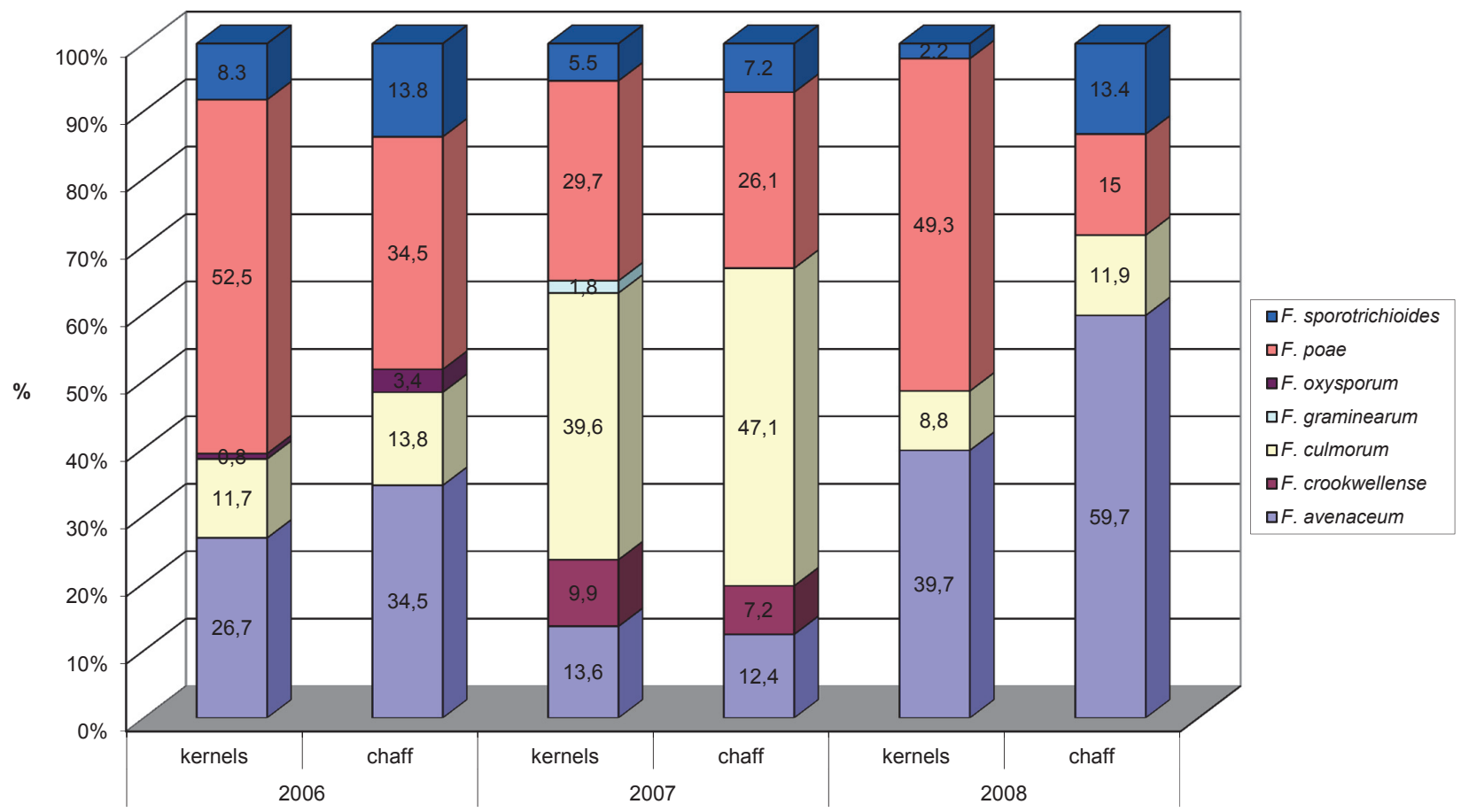

Fig. 2. Percentages of individual species of the genus Fusarium in infection of oat kernels and chaff in oat crops grown in the plots of Danko Plant Breeding Company and Strzelce Plant Breeding Company in 2006-2008.

\section{DISCUSSION}

In recent years, increased colonization of $F$. poae have been observed in oat grain (Mielniczuk, 2001; K i e c a $\mathrm{n}$ a et al. 2005; Mielniczuk et al. 2010) as well as in wheat, barley, and maize grain under natural infection conditions (L ô i v e k e, 2004; A r s e niuk and Góral, 2005; S adowski et al. 2007; Narkiewicz-Jodko et al. 2008; Choo et al. 2010; Ni e ls e n et al. 2010). This species has been isolated from maize cobs with symptoms of both pink and red rot (L o g rie co et al. 2003; A rseniuk and $\mathrm{G}$ or a l, 2005). The percentage proportion of the species $F$. poae in causing Fusarium head blight in cereals and oats as well as ear rot of maize changes depending on weather conditions ( $\mathrm{K} \mathrm{i} \mathrm{e} \mathrm{c} \mathrm{a} \mathrm{n} \mathrm{a,} \mathrm{1994;} \mathrm{M} \mathrm{i} \mathrm{e} \mathrm{ln} \mathrm{i-}$ czuk, 2001; Logrieco et al. 2003; Arseniuk and Góral, 2005; Ki ec an a and Mielniczuk, 2010). Fusarium poae usually occurs in colder regions (D o o h a n et al. 2003). Nevertheless, this species can be the casual agent of Fusarium head blight in cereals grown in regions with a hot and dry climate $(\mathrm{X} u$ et al. 2008). According to S a d ow ski et al. (2007), hot and dry weather during flowering and grain maturation in the period 2001-2002 proved to be beneficial for the growth of $F$. poae in grain of winter wheat grown in the Polish region of Żuławy.

According to Parry et al. (1995), optimal temperature for infection of ears by $F$. poae is $25^{\circ} \mathrm{C}$, though they can also be infected at a temperature of $15^{\circ} \mathrm{C}$ under the conditions of increased humidity. In the case of the present study, which was carried out under the conditions of a strictly controlled field experiment, temperature in excess of $20^{\circ} \mathrm{C}$ and increased humidity after inoculation of oat panicles seemed to be beneficial for the growth of $F$. poae in these organs.

To study different aspects of Fusarium head blight, the most effective inoculation methods are selected (Takeda and Heta, 1989; McCallum and Tekauz, 2002; Mielniczuk et al. 2004; Kiec a n a et al. 2006). In the present study, oat panicles were sprayed with a suspension of $F$. poae coinidia, because this method was considered to be the closest to natural infection.

Taking into account the varying virulence of strains within the population of the tested species (Mańka, 1989; Ki ecana and Kocyłak, 1999; K i e c a n a et al. 2005), the infectious material was prepared from $F$. poae strain with its pathogenicity proved by the method of $\mathrm{Mishra}$ and $\mathrm{Behr}$ (1976). The present strictly controlled field experiment demonstrates that artificial inoculation of panicles with $F$. poae strain no. 35 using the method applied proved to be effective, since it had an effect on reducing the number of kernels per panicle and inhibited their growth, but typical etiological signs were not observed on the panicle heads, similarly as in the case of wheat and oat kernels obtained from ears and panicles inoculated with $F$. poae (Schipilova and Gakaeva, 1997; K i e c a n a et al. 2005). 
The present study shows that infection of panicles with $F$. poae in 2008 had a similar effect on reducing kernels yield as infection of these organs of oats by $F$. culmorum in the period 1996-1998 (M i e ln i c z u k, 1999).

The results of quantitative and qualitative analysis of mycotoxins in oat grain infected with $F$. poae no. 35 has proved the ability of this species to produce group $\mathrm{A}$ and $\mathrm{B}$ trichothecene compounds ( $\mathrm{L}$ a $\mathrm{ng} \mathrm{s}$ e $\mathrm{t} \mathrm{h}$ et al. 1999; B ot talico and Perrone, 2002; Lo grieco et al. 2003; Des jardins, 2006; S c holle nberger et al. 2011).

In the present study, the presence of diacetoxyscirpenol (DAS) and HT-2 toxins from group A trichothecenes and nivalenol from type B trichothecenes was found in the case of most of the oat samples assayed. The above-mentioned metabolites are typical of the profile of mycotoxins produced by $F$. poae strains, both under laboratory and field conditions ( $\mathrm{K} \mathrm{i} \mathrm{e} \mathrm{c} \mathrm{a} \mathrm{n} \mathrm{a}$ and Perkowski, 1998; B ottalico and Perrone, 2002; Thrane et al. 2004; Kiecana et al. 2005; S tenglein, 2009; S chollenberger et al. 2011). The ability of $F$. poae to produce nivalenol has been proved in the colder regions of Japan (in the island of Hokkaido) and in Scandinavian countries (P e t ter s s o n, 1993; S u g i u r a et al. 1993; Lang seth et al. 1995; Petters on et al. 1995; Li u et al. 1998; Y li - M attil a et al. 2008). However, in 2008 the level of oat grain contamination with nivalenol was lower than in 2001 ( $\mathrm{K} \mathrm{i} \mathrm{e} \mathrm{c} \mathrm{a} \mathrm{n} \mathrm{a} \mathrm{et} \mathrm{al.}$ 2005). According to $\mathrm{S}$ te $\mathrm{ng}$ l e in (2009), A b r a ms o n et al. 1993, S a lla s et al. 1999, and J e s to i et al. 2008 inform that $F$. poae may produce DON whose presence was found in the grain of the oat genotypes tested.

Marasas et al. (1984, according to $\mathrm{De}$ s jardins, 2006) found the ability of $F$. poae strains originating from North America to produce small amounts of DAS and T-2 toxin. F. poae strain no. 35 in question did not produce T-2 toxin in oat grain. 15-monoacetoksyscirpenol (15-MAS), neosolaniol (NEO), and fusarenon-X (FUS X), often produced by $F$. poae, also were not found in the grain of the genotypes studied (Li u et al. 1998; Log ri e c o et al. 2003; T hr a ne et al. 2004). On the other hand, the investigated $F$. poae strain no. 35 produced STO and T-2 tetraol in infected oat grain. The former compound was also detected in kernels obtained from panicles inoculated with $F$. poae strain no. 37 in 2001 (K i e c a n a et al. 2005). The occurrence of T-2 tetraol was found in oat grain harvested from panicles naturally infected by this fungal species in plantations of Lubelskie and Podlaskie Voivodeships (K i e c a n a and P e rkow ski, 1998).

\section{Acknowledgements}

Research in year 2008 supported by the Ministry of Agriculture and Rural Development, project No HORhn-4040 dec-21/08.

\section{REFERENCES}

Abramson D., Clear R.M., Smith D.M.1993. Trichothecene production by Fusarium spp. isolated from Manitoba grain. Canadian J. Plant Pathol. 15: 147-152.

Arseniuk E., Góral T. 2005. Mikotoksyny fuzaryjne w ziarnie zbóż i kukurydzy. / Fusarium mycotoxins in cereal and maize grain. Hodowla Roślin i Nasiennictwo 3: 27-33. (in Polish)

Bottalico A., Perrone G. 2002. Toxigenic Fusarium species and mycotoxins associated with head blight in small-grain cereals in Europe. European J. Plant Pathol. 108: 611-624.

Choo T.M., Martin R.A., Savard M.E., Xue A.G. 2010. Fusarium head blight of barley in eastern Canada. $11^{\text {th }}$ European Fusarium Seminar "Fusarium - Mycotoxins, Taxonomy, Pathogenicity and Host Resistance". 20-23 September, Radzików, Poland: 101.

Desjardins A.E. 2006. Fusarium Mycotoxins Chemistry, Generics and Biology. The American Phytopath. Society. St. Paul, Minnesota USA APS Press.

Doohan F.M., Brennan J., Cook B.M.2003. Influence of climatic factors on Fusarium species pathogenic to cereal. Eur. J. Plant Pathol. 109: 755-768.

K iec a na I. 1994. Badania nad fuzariozą jęczmienia jarego (Hordeum vulgare L.) z uwzględnieniem podatności odmian i zawartości mikotoksyn w ziarnie. / Investigations on Fusarium head blight of spring barley (Hordeum vulgare L.) concerning susceptibility of cultivars and mycotoxins accumulation in kernels. Seria Wydawnicza - Rozprawy Naukowe, AR Lublin, 161: 1-49. (in Polish)

Kiecana I., Perkowski J. 1998. Zasiedlenie ziarna owsa (Avena sativa L.) przez toksynotwórcze grzyby Fusarium poae (Peck.) Wr. i Fusarium sporotrichioides Sherb. / Colonization of oat (Avena sativa L.) grain by toxigenic fungi Fusarium poae (Peck.) Wr. and Fusarium sporotrichioides Sherb. Zesz. Nauk. AR im. H. Kołłątaja w Krakowie 333: 881-884. (in Polish)

Kiecana I., Kocyłak E. 1999. Pathogenicity of Fusarium spp. on oats seedlings (Avena sativa L.). Plant Breed. Seed Sci. 43, 1: 91-99.

Kiecana I., Mielniczuk E.2010. Fusarium head blight of winter rye (Secale cereale L.). Acta Agrobot. 63 (1): 129-135.

Kiecana I., Mielniczuk E., Kaczmarek Z., Kostecki M., Goliński P. 2002. Scab response and moniliformin accumulation in kernels of oat genotypes inoculated with Fusarium avenaceum in Poland. Eur. J. Plant Pathol. 108: 245-251.

Kiecana I., Mielniczuk E., Perkowski J., Goliński P. 2005. Porażenie wiech przez Fusarium 
poae (Peck) Wollenw. oraz zawartość mikotoksyn w ziarnie owsa. / Infection of panicles with Fusarium poae (Peck) Wollenw. and mycotoxin content in oat grain. Acta Agrobot. 58, 2: 91-102. (in Polish)

Kiecana I., Mielniczuk E., Cegiełko M. 2006. Badanie podatności kłosów pszenicy ozimej (Triticum aestivum L.) na porażenie przez Fusarium avenaceum (Fr.) Sacc. / Investigations of winter wheat (Triticum aestivum L.) heads susceptibility to infection with $\mathrm{Fu}$ sarium avenaceum (Fr.) Sacc. Acta Agrophysica 8 (3): 629-636. (in Polish)

Langseth W., Hoie R., Gullord M. 1995. The influence of cultivars, location and climate on deoxynivalenol contamination in Norwegian oats 1985-1990. Acta Agric., Scand. Sect. B, Soil and Plant Sci. 45: 63-67. http://dx.doi.org/10.1080\%2F09064719509410935

Langseth W., Sundheim L., Liu W. 1997. Vegetative compatibility groups and trichothecene production in Fusarium poae. Cer. Res. Comm. 25, 3/2: 561-563.

Langseth W., Brenhoft A., Rundberget T., Kosiak B., Gareis M. 1999. Mycotoxin production and cytotoxicity of Fusarium strains isolated from Norwegian cereals. Mycopathologia, 144: 103-113.

Liu W.Z., Sundhrim L., Langseth W. 1998. Trichothecene production and the relationship to vegetative compatibility groups in Fusarium poae. Mycopathologia 140: 105-114.

Logrieco A., Bottalico A., Mule G., Moretti A., Perrone G. 2003. Epidemiology of toxigenic fungi and their associated mycotoxins for some Mediterranean crops. Eur. J. Plan Pathol. 109: 645-667.

Lőiveke H. 2004. Fusarim spp. as an important problem in cereal production in Estonia. Agronomijas Vestis (Latvian Jounal of Agronomy) 7: 84-88.

M a ń k a M. 1989. Patogeniczność wybranych gatunków z rodzaju Fusarium dla siewek zbóż. / Pathogenicity of selected Fusarium species to cereal seedlings. Rocz. AR Poznań, Rozprawy Naukowe: 1-64. (in Polish)

Mesterházy Á. 1978. Comparative analysis of artificial inoculation methods with Fusarium spp. on winter wheat varieties. Phytopathol. Z. 93, 1: 12-25. http://dx.doi. org/10.1111\%2Fj.1439-0434.1978.tb03632.x

McCallum B.D., Tekauz A. 2002. Influence of inoculation method and growth stage on Fusarium head blight in barley. Can. J. Plant Pathol. 24: 77-80. http:// dx.doi.org/10.1080\%2F07060660109506976

McMullen M.P., Stack R.W. 1983. Fusarium species in grassland soils. Can. J. Botany 61: 2530-2538.

Mielniczuk E. 1999. Badania nad fuzariozą wiech owsa (Avena sativa L.) z uwzględnieniem podatności odmian i zawartości mikotoksyn w ziarnie. Praca doktorska / Investigations on Fusarium head blight of oat (Avena sativa L.) in relation to the susceptibility of cultivars and mycotoxin content in grain. Docvtoral dissertation. (in Polish)

Mielniczuk E. 2001. The occurrence of Fusarium spp. on panicles of oat (Avena sativa L.). J. Plant Prot. Res. 41, 2: $173-180$.
Mielniczuk E., Kiecana I., Perkowski J. 2004. Susceptibility of oat genotypes to Fusarium crookwellense Burgess, Nelson and Toussoun infection and mycotoxin accumulation in kernels. Biologia, Bratislava 59, 6: 809-816

Mielniczuk E., Kiecana I., Cegiełko M. 2010. Grzyby zasiedlające materiał siewny owsa (Avena sati$v a$ L.). / Fungi colonizing seed material of oats (Avena sativa L.). Zesz. Probl. Post. Nauk Rol. 556: 879-890. (in Polish)

Mishra C.B.P., Behr L. 1976. Der Einfluss von Kulturfiltraten von Fusarium culmorum (W. G. Sm.) Sacc., Fusarium avenaceum (Fr.) Sacc. und Fusarium nivale (Fr.) Ces., Griphosphaeria nivalis Müller et v. Arx auf die Keimung des Weizen. Arch. Phytopathol. Pflazenschutz 12, 6: 373-377. (in German)

Narkiewicz-Jodko M., Gil Z., Wacławowicz R. 2008. Stan fitosanitarny ziarna pszenicy jarej w zależności od czynników agrotechnicznych oraz warunków pogody. / Phytosanitary status of spring wheat grain as dependent on cultivation factors and weather conditions. Zesz. Probl. Post. Nauk Rol. 531:137-143. (in Polish)

Nielsen L.K., Jensen J.D., Justesen A. F., Jřrgensen L.N. 2010. Cereal species preferences of the FHB complex in Denmark. $11^{\text {th }}$ European Fusarium Seminar "Fusarium - Mycotoxins, Taxonomy, Pathogenicity and Host Resistance". 20-23 September, Radzików, Poland: 189.

Parikka P., Kangas A., Hietaniemi V., Rämö S. 2010. Fusarium infection on barley and oats in Finland. $11^{\text {th }}$ European Fusarium Seminar "Fusarium - Mycotoxins, Taxonomy, Pathogenicity and Host Resistance". 20-23 September, Radzików, Poland: 195.

Parry D. W., Jenkinson P., McLeod L. 1995. Fusarium ear blight (scab) in small grain cereals a review. Plant Pathol. 44: 207-238. http://dx.doi. org/10.1111\%2Fj.1365-3059.1995.tb02773.x

Petters s on H. 1993. Trichothecene analysis in Swedish cereals 1987-1990. Hod. Rośl. Aklim. 37, 1/2, I: 37-42.

Pettersson H., Hedman R., Angstrom B., E1winger K., Fossum O. 1995. Nivalenol in Swedish cereals: occurrence, production and toxicity toward chickens. Food Add. Contam. 12: 373-376.

Sadowski Cz., Lenc L., Wyczling D. 2007. Grzyby z rodzaju Fusarium występujące w ziarnie wybranych odmian pszenicy uprawianej w rejonie Żuław. I Fungi from the genus Fusarium occurring on grain of chosen winter wheat cultivars grown in the region of Żuławy. Progress in Plant Protection/Postępy w Ochronie Roślin 47(2): 306-309. (in Polish)

Sallas B., Steffenson B.J., Casper Ch.Ch., Tacke B., Prom L.K., Fetch T.G. Jr, Schwarz P.B. 1999. Fusarium species pathogenic to barley and their associated mycotoxins. Plant Dis. 83: 667-674.

Schipilova N. P., Gakaeva T. Yu. 1997. The forms of manifestation of Fusarium head blight on the seeds and heads of cereal crops. Cer. Res. Comm. 25, 2/3: 815-816. 
Schollenberger M., Müller H-M., Liebscher M., Schlecker C., Berger M., Hermann W. 2011. Accumulation Kinetics of Three Scirpentriol-Based Toxins in Oats Inoculated in Vitro Isolates of Fusarium sporotrichioids and Fusarium poae. Toxins 2011, 3: 442-452. http://dx.doi.org/10.3390\%2Ftoxins 3050442

Shaner G. 2003. Epidemiology of Fusarium head blight of small grain cereals in North America. W: Leonard K.J.., Bushnell W.R. Fusarium head blight of wheat and barley. APS Press, The American Phytopath. Soc. St Paul, Minnesota: 84-119.

Stenglein S.A. 2009. Fusarium poae: a pathogen that needs more attention. J. Plant Pathol. 91 (1): 25-36.

Sugiura Y., Fukasaku K., Tanaka T., Matsui Y., Ucho Y. 1993. Fusarium poae and Fusarium crookwellense, fungi responsible for the natural occurrence of nivalenol in Hokkaido. Appl. Microbiol. 59, 10: 3334-3338.

Takeda K., Heta H. 1989. Establishing the testing method and a search for the resistant varieties to Fusarium head blight in barley. Jap. J. Bread. 39: 209-216. http:// dx.doi.org/10.1270\%2Fjsbbs1951.39.203

Tekauz A., McCallum B., Ames N., Mitchell Fetch J. 2004. Fusarium head blight of oat - current status in western $\mathrm{Ca}$ nada. Can. J. Plant Pathol. 26, 4: 473-479. http://dx.doi. org/10.1080\%2F07060660409507167

Thrane U., Adler A., Clasen P.E., Galvano F., Ritieni A. 2004. Diversity in metabolite production by Fusarium langsethiae, Fusarium poae and Fusarium sporotrichioides. International J. Food Microbiol. 95: 257-266. http:// dx.doi.org/10.1016\%2Fj.ijfoodmicro.2003.12.005

Tottman D.R. 1987. The Decimal code for the growth stages of cereals with illustrations. BCPC Publications Reprinted from the Annals of Applied Biology, 110. Occasional Publication 4: 441-454. http://dx.doi.org /10.1111\%2Fj.1744-7348.1987.tb03275.x

Xu X., Nicholson P., Thomsett M.A., Simpson D., Cooke B.M., Doohan F.M., Brennan J., Monaghan S., Moretti A., Mule G., Hornok L., Beki E., Tatnell J., Ritieni A., Edwards S.G. 2008. Relationship between the fungal complex causing Fusarium head blight of wheat and environmental conditions. Phytopathology 98: 69-78. http://dx.doi.org/10.1094\%2FPHYTO-98-1-0069

Yili-Mattila T., Paavanen-Hubtala S., Jestoi M., Parikka P., Hietaniemi V., Gagkaeva T., Sarlin T., Haikara A., Laaksonen S., Rizzo A. 2008. Real-time PCR detection and quantification of Fusarium poae, F. graminearum, $F$. sporotrichioides and $F$. langsethiae in cereal grains in Finland and Russia. Arch. Phytopath. Plant Prot. 41: 243-260.

Żu k B. 1989. Biometria stosowana. Państwowe Wydawnictwo Naukowe, Warszawa. (in Polish)

\section{Występowanie Fusarium poae (Peck) Wollenw. na wiechach owsa (Avena sativa L.) i jego szkodliwość}

\section{Streszczenie}

Obserwacje polowe wiech owsa przeprowadzone w latach 2006-2007 na polach Hodowli Roślin Danko i w 2008 roku na polach Hodowli Roślin Strzelce, wykazały w każdym sezonie wegetacji występowanie wiech z objawami fuzariozy. W 2006 roku odsetek takich wiech wynosił od 0,25 do $1,5 \%$, w 2007 roku od 2,0 do 9,0\%, zaś w 2008 roku od 0,5 do 8,0\%. Głównym sprawcą fuzariozy wiech był gatunek Fusarium poae. W badaniach ze sztucznym zakażaniem wiech 12 genotypów owsa szczepem $\mathrm{nr} 35$ Fusarium poae, przeprowadzonych w 2008 roku na polach doświadczalnych koło Zamościa, po zbiorze roślin w fazie dojrzałości pełnej ziarna określano liczbę ziarniaków w wiesze, plon ziarna z 40 wiech $(4 \times 10$ wiech $)$ oraz masę 1000 ziaren (MTZ). Najmniejszą redukcję liczby ziarniaków w wiesze w porównaniu do kontroli zanotowano w przypadku odmiany Krezus (88,69\% kontroli), największą zaś u odmiany Szakal (22,46\% kontroli). Najmniejszą obniżką plonu ziarna w wyniku inokulacji wiech przez $F$. poae charakteryzował się ród hodowlany STH 8107 (69,76\% kontroli), największą zaś ród hodowlany CHD 1430/02 (14,26\% kontroli). Najmniejszą redukcję MTZ w porównaniu do kontroli stwierdzono w przypadku rodu hodowlanego STH 8107 (96,46\% kontroli), największą natomiast u rodu hodowlanego CHD 1430/02 (45,06\% kontroli). W porażonych ziarniakach owsa stwierdzono obecność drugorzędowych metabolitów wtórnych $F$. poae, związków trichotecenowych z grupy A: HT-2 toksyny (od 0 do $0,013 \mathrm{mg} \times \mathrm{kg}^{-1}$ ), diacetoksyscirpenolu (DAS) (od 0 do $\left.0,002 \mathrm{mg} \times \mathrm{kg}^{-1}\right)$, T-2 tetraolu (od 0,001 do $0,014 \mathrm{mg} \times \mathrm{g}^{-1}$ ) i scirpentriolu (od 0,008 do $0,074 \mathrm{mg} \times \mathrm{kg}^{-1}$ ). W ziarnie owsa pochodzącym z wiech sztucznie zakażanych Fusarium poae były również obecne trichoteceny z grupy B: niwalenol (od 0 do $0,157 \mathrm{mg} \times \mathrm{g}^{-1}$ ), deoksyniwalenol (DON) (od 0 do $\left.0,127 \mathrm{mg} \times \mathrm{kg}^{-1}\right)$ oraz jego acetylowe pochodne 3- AcDON (od 0 do $0,059 \mathrm{mg} \times \mathrm{kg}^{-1}$ ) i 15-Ac DON (od 0 do $\left.0,288 \mathrm{mg} \times \mathrm{kg}^{-1}\right)$. 
